\title{
Teat number, hairiness and set of ears in a Piétrain cross: variation and effects on performance traits
}

\begin{abstract}
Summary
$\mathrm{A} \mathrm{F}_{2}$-resource population has been constructed by mating five Piétrain boars to one Landrace, one Large White and twelve Landrace $\times$ Large White crossbred sows in the parent generation. From 116 animals of the $F_{1}$ and from 2706 animals of the $F_{2}$ teat number was recorded with reference to side. The average number of teats in the $F_{1}$-generation was $7.1 \pm 0.5$ on the left body side and $7.0 \pm 0.6$ on the right body side. The $F_{2}$-offspring had an average teat number of $6.9 \pm 0.6$ on both sides. The phenotypic and genetic correlations between left and right side teat number were 0.56 and 0.96 , respectively. A Bayesian heritability estimate of $0.23 \pm 0.05$ was obtained for total teat number.

The density of hairiness was scored into the categories little, normal and very hairy and the set of ears into the categories prick-eared, intermediate and lop-eared. Data of $113 \mathrm{~F}_{1}$-animals and $2770 \mathrm{~F}_{2}$-animals were available. Bayesian analyses provided heritabilities of $0.27 \pm 0.07$ for the density of hairiness and of $0.37 \pm 0.08$ for the set of ears. In further analyses the traits teat number, hairiness and set of ears were taken as phenotypic markers. The effect of teat number on growth development during pregnancy and on several fatness traits of the carcass was significant. The set of ears showed a significant influence on growth traits only. Significant effects on birth weight and different carcass traits could be found for the density of hairiness. From the phenotypic effects it can be concluded that "lop ear" is linked to Landrace alleles and "little hairy" is linked to Piétrain alleles.
\end{abstract}

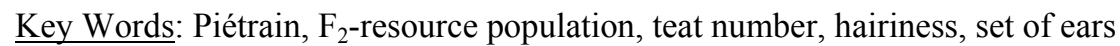

\section{Zusammenfassung}

Titel der Arbeit: Zitzenzahl, Behaarung und Ohrformen in einer Piétrainkreuzung: Variation und Leistungseffekte

Um eine $\mathrm{F}_{2}$-Ressourcen-Population $\mathrm{zu}$ erstellen, wurden in der Elterngeneration fünf Piétraineber an eine Landrassesau, eine Large White Sau und zwölf Landrasse $\times$ Large White Kreuzungssauen angepaart. Die Anzahl der Zitzen auf jeder Körperseite wurde bei $116 \mathrm{~F}_{1}$ - und $2706 \mathrm{~F}_{2}$-Tieren festgestellt. In der $\mathrm{F}_{1}$-Generation betrug

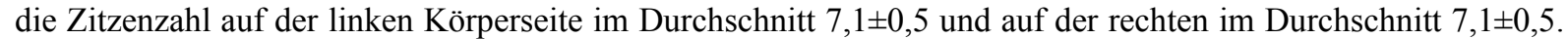
Die $F_{2}$-Nachkommen hatten eine durchschnittliche Zitzenzahl von 6,9 $\pm 0,6$ auf beiden Körperseiten. Die phänotypische und die genetische Korrelation zwischen den Zitzenzahlen auf der linken und rechten Körperseite waren 0,56 und 0,96. Eine Heritabilität für die Gesamtzitzenanzahl von 0,23 $\pm 0,05$ wurde mit einem BayesAnsatz geschätzt.

Die Stärke der Behaarung wurde unterschieden in wenig, normal und stark behaart, die Haltung der Ohren in Stehohr, Mischform und Schlappohr. Daten von $113 \mathrm{~F}_{1}$-Tieren und $2770 \mathrm{~F}_{2}$-Tieren waren verfügbar. Nach dem Bayes-Verfahren durchgeführte Analysen lieferten Heritabiliäten von 0,27 $\pm 0,07$ für die Stärke der Behaarung und von 0,37 $\pm 0,08$ für die Ohrform. In weiteren Analysen wurden die Zitzenzahl, die Behaarung und die Ohrform als phänotypische Marker betrachtet. Der Effekt der Zitzenzahl war signifikant für die Wachstumsentwicklung während der Trächtigkeit und für zahlreiche Verfettungsmerkmale des Schlachtkörpers. Die Haltung der Ohren zeigte nur bei Wachstumsmerkmalen einen signifikanten Einfluß. Signifikante Effekte auf das Geburtsgewicht und auf verschiedene Schlachtkörpermerkmale konnten für die Stärke der Behaarung gefunden werden. Die phänotypischen Effekte zeigten, daß das „Schlappohr“ mit Allelen der Landrasse und „geringe Behaarung“ mit Allelen des Piétrainschweines in Verbindung steht.

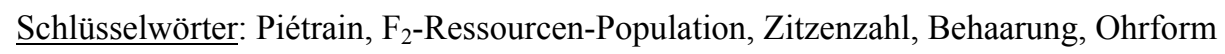


1. Introduction

\section{Teat number}

The typical number of teats in domestic breeds and their constancy varies widely. According to LÖFFLER (1991), the characteristic pair number of nipples is one in sheep, goats, and horses, two in cattle, four in cats, four to six in dogs, and six to eight in pigs. NACHTSHEIM (1925) found a higher variation of four to nine pairs of teats in pigs. He distinguished three categories of teats: a) the "normal" teats, in general 14 teats, which are symmetrically distributed in two rows, b) the supernumerary teats, frequently observed between the third and fourth pair of teats and c) the rudimentary teats. They are also a kind of supernumerary teats, which are placed between the thighs or on the scrotum of boars. For the rudimentary teats WENTWORTH (1913) found a recessive, sex-linked mode of inheritance which was however not confirmed by NACHTSHEIM (1925). The observed variation in total teat number and the occurrence of asymmetrical placement is due to the absence of teats. NACHTSHEIM (1925) found that as a rule the nipples of the second and sixth pair are incomplete or one pair or both pairs are absent. Asymmetry in placement of the teats occurs if one pair of teats is incomplete. WENTWORTH (1913) distinguished two patterns of asymmetry, which he denoted as "suppressed nipple pattern" and "triangular pattern". The first described pattern shows a lack of one teat in a pair, but all other pairs are symmetrically distributed. In the "triangular pattern" the incomplete teat pair and one neighbouring complete pair generate a triangle. SCHMIDT et al. (1936) found a proportion of $38 \%$, WILLHAM and WHATLEY (1963) reported a proportion of 40 $\%$ and MAYER and PIRCHNER (1995) a proportion of $34 \%$ asymmetrical animals. A high correlation between asymmetry and inverted nipples of $0.69 \pm 0.02$ was computed by MAYER and PIRCHNER (1995), but they could not prove an additivegenetic inheritance of asymmetry. This is concordant with PLUM (1938) who assumed that hereditary factors are of minor importance for asymmetry.

The absence of the second and the sixth pair of teats is common in the European wild pig (Sus scrofa), thus ten teats are the most frequent number (NACHTSHEIM, 1925). SCHMIDT et al. (1936) also mentioned that in the wild pig also animals with eight or twelve teats occur, but a number of ten teats is the most frequent. NACHTSHEIM (1925) explained the higher number of nipples in the Western domestic breeds by crossbreeding with the Asian Sus vittatus pigs. HALEY et al. (1995) reported a number of 17 nipples in purebred Meishans. An overview of the average teat number in Polish pig breeds (ORZECHOWSKA and MUCHA, 1998) clearly demonstrates the intermediate position of the Western breeds: the average teat number in Polish Large White, Polish Landrace, Belgian Landrace, Zlotniki White, Pulawy, Zlotniki Pied, Hampshire, Duroc and Piétrain was reported with 14.7, 14.7, 13.8, 14.2, 14.9, 14.0, 13.9, 13.4 and 13.9, respectively. In Table 1 further studies on the average number of teats are presented. A wide range of heritability estimates from 0.07 to 0.79 has been found (Table 1), most of them situated in an interval from 0.30 to 0.50 . Numerous estimations of heritability for nipple number were carried out owing to the high economic importance of this trait. Especially the number of good teats is important for the mothering ability and reproductive performance of a sow, because a sow seldom weans more piglets than the number of teats it has. But knowledge on the number of genes responsible for the inheritance of nipple number is limited. In an early study 
SCHMIDT et al. (1936) suggested an intermediate mode of inheritance possibly inclining to the parent with the smaller number of teats, but left the question open how many genes could be involved. It was found by LIU et al. (1995) that the defect of inverted teats in the Shanxi Black breed is due to a single autosomal recessive gene.

Table 1

Number of animals $(\mathrm{N})$, average teat number with Standard Error $( \pm \mathrm{SE})$ and heritability estimates $\left(\mathrm{h}^{2}\right)$ of teat number in different breeds (Anzahl Tiere $(\mathrm{N})$, durchschnittliche Zizenzahl mit Standardfehler $( \pm \mathrm{SE})$ und Heritabilitätsschätzwerte für die Zitzenzahl bei verschiedenen Rassen)

\begin{tabular}{|c|c|c|c|c|}
\hline Author & $\mathbf{N}$ & Breed & Teat number \pm SE & $\mathbf{h}^{2}$ \\
\hline \multirow[t]{2}{*}{ Allen et al., 1959} & 199 & Landrace & $13.7 \pm .06$ & .59 \\
\hline & 154 & Poland China & $12.5 \pm .08$ & .59 \\
\hline Enfield and Rempel, 1961 & 3565 & Minnesota No. 1 & $13.5 \pm .01$ & $.10-.23$ \\
\hline \multirow{3}{*}{ Skjervold, 1963} & 2180 & Landrace & $14.2 \pm .02$ & $.22-.28$ \\
\hline & 1362 & Large White & $14.4 \pm .02$ & $.16-.30$ \\
\hline & 1473 & Landrace $\times$ Large White & $14.3 \pm .03$ & $.29-.36$ \\
\hline Willham and Whatley, 1963 & 18704 & $\begin{array}{l}\text { Beltsville No.1, Hampshire, Duroc } \\
\text { etc. }\end{array}$ & $\begin{array}{l}6.2 \pm .01 \\
\text { per side }\end{array}$ & $.28-.40$ \\
\hline \multirow[t]{2}{*}{ Hanset and Camerlynck, 1974} & 4342 & Piétrain & $13.2 \pm .02$ & .46 \\
\hline & 1579 & Belgian Landrace & $14.0 \pm .03$ & .34 \\
\hline Pumfrey et al., 1980 & 7513 & Nebraska Gene Pool & $13.1 \pm .01$ & $.32-.44$ \\
\hline \multirow[t]{2}{*}{ Clayton et al., 1981} & 2148 & Large White & 14 (mode) & $.07-.48$ \\
\hline & 3202 & Landrace & & \\
\hline \multirow[t]{3}{*}{ Smith et al., 1986} & 456 & Large White & 14.4 & .20 \\
\hline & 1370 & Landrace & 14.3 & \\
\hline & 78 & Synthetics & 14.1 & \\
\hline \multirow[t]{9}{*}{ McKay and Rahnefeld, 1990} & 5351 & Lacombe & $14.1 \pm .2$ & .23 \\
\hline & 4711 & Yorkshire & $13.8 \pm .2$ & .32 \\
\hline & 4033 & Lacombe $\times$ Yorkshire & $13.0 \pm .2$ & .20 \\
\hline & 1083 & Landrace & $14.4 \pm .3$ & .39 \\
\hline & 3803 & Yorkshire & $13.5 \pm .2$ & .44 \\
\hline & 2134 & Hampshire & $12.7 \pm .3$ & .45 \\
\hline & 2130 & Landrace-Yorkshire-rotation & $14.0 \pm .3$ & .43 \\
\hline & 2504 & Landrace $\times$ Yorkshire & $14.0 \pm .2$ & .27 \\
\hline & 1464 & Landrace $\times$ Hampshire & $13.6 \pm .3$ & .47 \\
\hline \multirow[t]{2}{*}{ Kuciel and Chvatalova, 1992} & 1848 & Czech improved white pig $q$ & 14.3 & $.32-.53$ \\
\hline & 1894 & Czech improved white pig & 14.4 & $.35-.42$ \\
\hline Gaur and Chhabra, 1995 & 2802 & Large White & $14.1 \pm .07$ & .15 \\
\hline \multirow[t]{2}{*}{ Ligonesche et al., 1995} & 18632 & Sire line & - & .25 \\
\hline & 19109 & Dam line & - & .25 \\
\hline Seo et al., 1996 & 13454 & Duroc, Landrace, Large White & - & $.07-.09$ \\
\hline Wang et al., 2000 & 9898 & Landrace & - & .66 \\
\hline Zhang et al., 2000 & 9680 & Chinese $\times$ European Tiameslan & $15.4 \pm .01$ & $.43-.53$ \\
\hline Lee and Wang, 2001 & - & Landrace, Yorkshire etc. & - & $.54-.79$ \\
\hline Hirooka et al., 2002 & 1173 & Meishan $\times$ Dutch pig lines & 15.4 & .53 \\
\hline
\end{tabular}

Recently, first studies showed evidence for quantitative trait loci (QTL) on Sus scrofa chromosomes 1, 2, 3, 6, 7, 8, 10,11, 12 and 16 (WADA et al., 2000; BIDANEL et al., 2000; ROHRER, 2000; CASSADY et al., 2001; HIROOKA et al., 2001). These results indicate a polygenic inheritance of the teat number.

\section{Hairiness}

The density of hairiness is determined by the number of hair follicles. WATSON and MOORE (1990) state that the total hair follicle population in the pig, as in many other mammals, is established before birth and a postnatal initiation does not occur. The inheritance of a nearly hairless phenotype, caused by a reduced number of hair 
follicles, is described by ROBERTS and CARROLL (1931) in Mexican Poland Chinas. A simple intermediate mode of inheritance was found, where the recessive phenotype was partially hairless, the intermediate had a reduced amount of hair and the dominant was normal hirsute. The described form of hypotrichosis (partial hairlessness) was not due to a nutritional deficiency of iodine, where the piglets are born either dead or die within few hours (ROBERTS and CARROLL, 1931). A lethal inherited type of hypotrichosis has been investigated by MEYER and DROMMER (1968). This kind of hypotrichosis is inherited by an autosomal dominant gene. Homozygous animals die within ten days and the heterozygous piglets show a decreased vitality.

Another type of hairiness, the woolly hair, was mentioned by RHOAD (1934) in Brazilian Canastrao pigs. This hair condition, shown e.g. by the Mangalitza breed, is inherited by a single autosomal dominant gene being independent from coat colour, coat pattern and sex. Some of the woolly pigs also possessed the gene for partial hairlessness, which seems to be inherited independently from the woolly hair condition. The arrangement of whorls or swirls in the hair of pigs was explained with the interaction of two dominant genes (NORDBY, 1932).

\section{Set of ears}

The set of ears in pigs ranges from prick to lop. Intermediate characters of these extremes often appear, especially in crossbred pigs. In domestic pigs the Large White is a typical breed with erect ears and the Landrace a typical lop-eared breed. An intermediate character is shown by the Piétrains with almost erect ears, which are directed forwards (PORTER and TEBBIT, 1993). The mode of inheritance of the set of ears is not well investigated so far. PORTER and TEBBIT (1993) postulated that lop is generally simple dominant and prick simple recessive, but CARR-SAUNDERS (1922) found a simple dominance of the prick form in crosses with prick-eared Berkshires and lop-eared Large Blacks.

In this paper we firstly present data on the variation of teat number, hairiness and set of ears in a $F_{1}$ and a $F_{2}$ of a Piétrain cross. Secondly, we provide Bayesian heritability estimates and analyses where the number of teats, the hairiness and the set of ears were used as a marker for direct or linked effects on several growth and carcass traits.

\section{Animals}

A three-generation crossbreeding experiment was carried out by crossing five purebred and genetically stress resistant Piétrain boars with one Landrace, one Large White and twelve Landrace $\times$ Large White crossbred sows. A number of 14 fullsib groups, consisting of a total of 14 boars and 120 sows, produced 4258 born piglets by repeated fullsib matings.

These $\mathrm{F}_{2}$-animals were reared and fattened on the experimental piggery Hohenschulen (ten pigs/pen) and on the research station "Alte MPA" (two pigs/pen) of the ChristianAlbrechts-University of Kiel. All culled $F_{1}$-sows and $F_{1}$-boars and the finished $F_{2}$-pigs were slaughtered in a commercial abattoir.

\section{Registering teat numbers}

Teat number was recorded in both generations with reference to side. Additional and 
abnormal teats were not considered. The teats of the $\mathrm{F}_{1}$-animals were counted on the live animal on the day of slaughter. Teat number of the $\mathrm{F}_{2}$-offspring was counted during the slaughter process after blazing off the bristles on the unseparated carcass. Data from $116 \mathrm{~F}_{1}$ - and $2706 \mathrm{~F}_{2}$-animals were registered this way.

\section{Judging hairiness and the set of ears}

The density of hairiness was subdivided into the three categories little hairy (1), normal hairy (2) and very hairy (3). According to the founder lines the set of ears was evaluated in the categories prick-eared (1, Large White type), intermediate (2, Piétrain type or other intermediate forms) and lop-eared (3, Landrace type). The judgement was always done by the same person at the end of the fattening period. A data set of 113 observations from $F_{1}$ and 2770 observations from the $F_{2}$ was recorded.

\section{Growth and carcass measurements}

A detailed description of the recorded growth and carcass traits (different weights and corresponding daily gains, the FOM protocol and performance test data, see Table 2) in the $F_{2}$-generation can be found in BORCHERS (2002).

\section{Statistical methods}

a) Estimation of heritabilities for teat number, hairiness and set of ears

A first analysis of the data using the MIXED procedure of the SAS package (SAS, 1992) with sire, dam and litter as random effects did not show any significance for the following effects: parity (first or higher), generation $\left(\mathrm{F}_{1}\right.$ or $\left.\mathrm{F}_{2}\right)$ and a linear regression on pregnancy length. Sex (female or castrated male) was significant for teat number and set of ears, a linear regression on litter size for set of ears and a seasonal effect (month of slaughter for teat number and month of judging for hairiness and set of ears) for all three characters. Therefore, the following animal models were used:

teat number:

$$
\begin{aligned}
& \mathrm{y}_{\mathrm{ijklm}}=\mu+\mathrm{SE}_{\mathrm{i}}+\mathrm{SN}_{\mathrm{j}}+\mathrm{li}_{\mathrm{k}}+\mathrm{an}_{\mathrm{l}}+\mathrm{e}_{\mathrm{ijklm}}, \\
& \mathrm{y}_{\mathrm{ijklm}}=\mu+\mathrm{SN}_{\mathrm{i}}+\mathrm{li}_{\mathrm{j}}+\mathrm{ma}_{\mathrm{k}}+\mathrm{an}_{\mathrm{l}}+\mathrm{e}_{\mathrm{ijklm}}, \\
& \mathrm{y}_{\mathrm{ijklmn}}=\mu+\mathrm{SE}_{\mathrm{i}}+\mathrm{SN}_{\mathrm{j}}+\mathrm{b} \cdot \mathrm{l} \mathrm{s}+\mathrm{li}_{\mathrm{k}}+\mathrm{ma}_{\mathrm{l}}+\mathrm{an}_{\mathrm{m}}+\mathrm{e}_{\mathrm{ijklmn}},
\end{aligned}
$$

hairiness:

set of ears:

where $y_{i j k l m}, y_{i j k l m n}$ are the individual observations for the considered trait, $\mu$ is the fixed effect of the overall mean, $\mathrm{SE}_{\mathrm{i}}$ is the fixed effect of the sex ( $\mathrm{i}=$ female or castrated male), $\mathrm{SN}_{\mathrm{i}}, \mathrm{SN}_{\mathrm{j}}$ are the fixed seasonal effects $(\mathrm{i}=1 . . .29$ for teat number, $\mathrm{i}, \mathrm{j}=$ $1 . . .25$ for hairiness and set of ears), $b$ is a linear regression on the litter size (ls) in the data of the set of ears, $\mathrm{li}_{\mathrm{j}}, \mathrm{li}_{\mathrm{k}}$ are random environmental effects of each litter $(\mathrm{i}, \mathrm{k},=$ $1 . .416), \mathrm{ma}_{\mathrm{k}}, \mathrm{ma}_{\mathrm{l}}$ are random maternal effects of each dam $(\mathrm{k}, 1=1 \ldots 126), \mathrm{an}_{1}, \mathrm{an}_{\mathrm{m}}$, are the breeding values of each animal $(1=1 \ldots 2853$ for teat number, $1, \mathrm{~m}=1 \ldots 2883$ for hairiness and set of ears), and $\mathrm{e}_{\mathrm{ijklm}}, \mathrm{e}_{\mathrm{ijklmn}}$ are the residuals.

Bayesian estimates for variance components were computed with the help of the LMMG program (REINSCH, 1996). Posterior means are reported as estimates for the variance components. Heritabilities for the left and right side teat number and the difference of sides were also calculated with the described statistical model. According to WILLHAM and WHATLEY (1963), the phenotypic and the genetic correlation between left and right side nipple number was estimated as:

$$
r_{g(1 / r)}=\frac{\sigma_{T T}^{2}-\sigma_{\mathrm{DT}}^{2}}{\sigma_{\mathrm{TT}}^{2}+\sigma_{\mathrm{DT}}^{2}}
$$


Table 2

Effect classes and regressor variables for the analyses of the influence of teat number, set of ears and hairiness on performance (Effektstufen und Regressorvariable für die Analyse der Leistungseffekte der Zitzenzahl, der Ohrform und der Behaarung)

\begin{tabular}{|c|c|c|c|c|c|c|c|c|c|c|}
\hline trait & $\begin{array}{l}\text { „ear“, „hair““ } \\
\text { teat number, }\end{array}$ & sex & parity & $\begin{array}{c}\text { seasonal } \\
\text { group }\end{array}$ & $\begin{array}{c}\begin{array}{c}\text { day of } \\
\text { slaughter }\end{array} \\
\end{array}$ & sires & dams & $\begin{array}{l}\text { litter } \\
\text { effect }\end{array}$ & linear regression on & linear regression on \\
\hline birth weight (kg) & 3 or 4 & 2 & 2 & 29 & - & 14 & 120 & 406 & litter size & pregnancy length \\
\hline weaning weight (kg) & 3 or 4 & 2 & 2 & 29 & - & 14 & 119 & 400 & suckling length & - \\
\hline starting weight (kg) & 3 or 4 & 2 & 2 & 74 & - & 14 & 119 & 399 & age at starting & - \\
\hline end weight (kg) & 3 or 4 & 2 & 2 & 34 & - & 14 & 114 & 394 & age at slaughter & - \\
\hline daily gain. pregnancy (g) & 3 or 4 & 2 & 2 & 29 & - & 14 & 120 & 406 & litter size & pregnancy length \\
\hline daily gain. suckling period (g) & 3 or 4 & 2 & 2 & 29 & - & 14 & 119 & 400 & suckling length & - \\
\hline daily gain. rearing period (g) & 3 or 4 & 2 & 2 & 74 & - & 14 & 119 & 399 & weaning weight & starting weight \\
\hline daily gain. fattening period (g) & 3 or 4 & 2 & 2 & 34 & - & 14 & 114 & 394 & starting weight & end weight \\
\hline live daily gain $(\mathrm{g})$ & 3 or 4 & 2 & 2 & 34 & - & 14 & 114 & 394 & end weight & - \\
\hline live-weight at slaughter (kg) & 3 or 4 & 2 & 2 & 34 & 107 & 14 & 114 & 394 & - & - \\
\hline carcass weight $(\mathrm{kg})$ & 3 or 4 & 2 & 2 & 34 & 107 & 14 & 114 & 394 & - & - \\
\hline dressing out (\%) & 3 or 4 & 2 & 2 & 34 & 107 & 14 & 114 & 394 & - & - \\
\hline abdominal fat (g) & 3 or 4 & 2 & 2 & 34 & - & 14 & 114 & 394 & carcass weight & - \\
\hline loin fat depth (mm) & 3 or 4 & 2 & 2 & 34 & - & 14 & 114 & 394 & carcass weight & - \\
\hline loin eye depth (mm) & 3 or 4 & 2 & 2 & 34 & - & 14 & 114 & 394 & carcass weight & - \\
\hline lean meat content (\%) & 3 or 4 & 2 & 2 & 34 & - & 14 & 114 & 394 & carcass weight & - \\
\hline reflectance (1 h p.m.) & 3 or 4 & 2 & 2 & 34 & 106 & 14 & 114 & 394 & - & - \\
\hline $\mathrm{pH}_{1}$ (loin) & 3 or 4 & 2 & 2 & 34 & 107 & 14 & 114 & 394 & - & - \\
\hline $\mathrm{pH}_{24}$ (loin) & 3 or 4 & 2 & 2 & 34 & 107 & 14 & 114 & 394 & - & - \\
\hline $\mathrm{pH}_{24}$ (ham) & 3 or 4 & 2 & 2 & 34 & 107 & 14 & 114 & 394 & - & - \\
\hline conductivity (mS/cm. 1 h p.m.) & 3 or 4 & 2 & 2 & 34 & 107 & 14 & 114 & 394 & - & - \\
\hline conductivity (mS/cm. 24 h p.m.) & 3 or 4 & 2 & 2 & 34 & 107 & 14 & 114 & 394 & - & - \\
\hline meat brightness (24 h p.m.) & 3 or 4 & 2 & 2 & 34 & 107 & 14 & 114 & 394 & - & - \\
\hline carcass length $(\mathrm{cm})$ & 3 or 4 & 2 & 2 & 34 & - & 14 & 114 & 394 & carcass weight & - \\
\hline fat thickness neck (cm) & 3 or 4 & 2 & 2 & 34 & - & 14 & 114 & 394 & carcass weight & - \\
\hline fat thickness middle of back $(\mathrm{cm})$ & 3 or 4 & 2 & 2 & 34 & - & 14 & 114 & 394 & carcass weight & - \\
\hline fat thickness end of back $(\mathrm{cm})$ & 3 or 4 & 2 & 2 & 34 & - & 14 & 114 & 394 & carcass weight & - \\
\hline fat thickness at $m$. latissimus dorsi (cm) & 3 or 4 & 2 & 2 & 34 & - & 14 & 114 & 394 & carcass weight & - \\
\hline fat thickness over the loin muscle (cm) & 3 or 4 & 2 & 2 & 34 & - & 14 & 114 & 394 & carcass weight & - \\
\hline loin fat area $\left(\mathrm{cm}^{2}\right)$ & 3 or 4 & 2 & 2 & 34 & - & 14 & 114 & 394 & carcass weight & - \\
\hline loin eye area $\left(\mathrm{cm}^{2}\right)$ & 3 or 4 & 2 & 2 & 34 & - & 14 & 114 & 394 & carcass weight & - \\
\hline meat-fat-ratio & 3 or 4 & 2 & 2 & 34 & - & 14 & 114 & 394 & carcass weight & - \\
\hline belly fatness score (1-9) & 3 or 4 & 2 & 2 & 34 & - & 14 & 114 & 394 & carcass weight & - \\
\hline ham weight $(\mathrm{kg})$ & 3 or 4 & 2 & 2 & 34 & - & 14 & 114 & 394 & carcass weight & - \\
\hline proportion of ham in carcass (cold) (\%) & 3 or 4 & 2 & 2 & 34 & - & 14 & 114 & 394 & carcass weight & - \\
\hline
\end{tabular}


where $\sigma_{\mathrm{TT}}^{2}$ is the phenotypic or additive-genetic variance of the total nipple number and $\sigma_{\mathrm{DT}}^{2}$ is the phenotypic or additive-genetic variance of the absolute (sign ignored) difference between left and right side nipples.

b) Relationship of teat number, hairiness and set of ears with growth and carcass traits The statistical analysis was performed using the procedure MIXED of the SAS package (SAS, 1992). In a mixed model sire, dam and common litter environment were considered as random effects and sex (female or castrated male), parity (first or higher), day of slaughter and the seasonal group were further effects. The seasonal groups were defined as 'month of mating' for daily gain during the pregnancy, 'month of birth' for birth weight and daily gain during the suckling period, 'month of weaning' for weaning weight, 'the rearing group' (piglets weaned at the same month and stalled to the same flatdeck) for starting weight and daily gain during the rearing period, 'the fattening group' (pigs started at the same month and stalled to the same farm) for end weight, daily gain during the fattening period, live daily gain and all the carcass traits.

To investigate the impact on growth and carcass traits the teat number was grouped into the classes $\leq 12$ teats, 13 teats, 14 teats and $\geq 15$ teats, the set of ears with the classes prick-eared, intermediate and lop-eared and the hairiness with the classes little, normal and very hairy. The number of classes of each effect and the regressor variables are listed in Table 2 for each growth and carcass trait.

\section{$3 . \quad$ Results and discussion}

\section{Teat number}

The Figure shows the distribution of total teat numbers in the $F_{1}$ (white column) and $F_{2}$ (grey column). Total teat number varied from eleven to 17 in the $F_{1}$ and from seven to 17 in the $\mathrm{F}_{2}$.

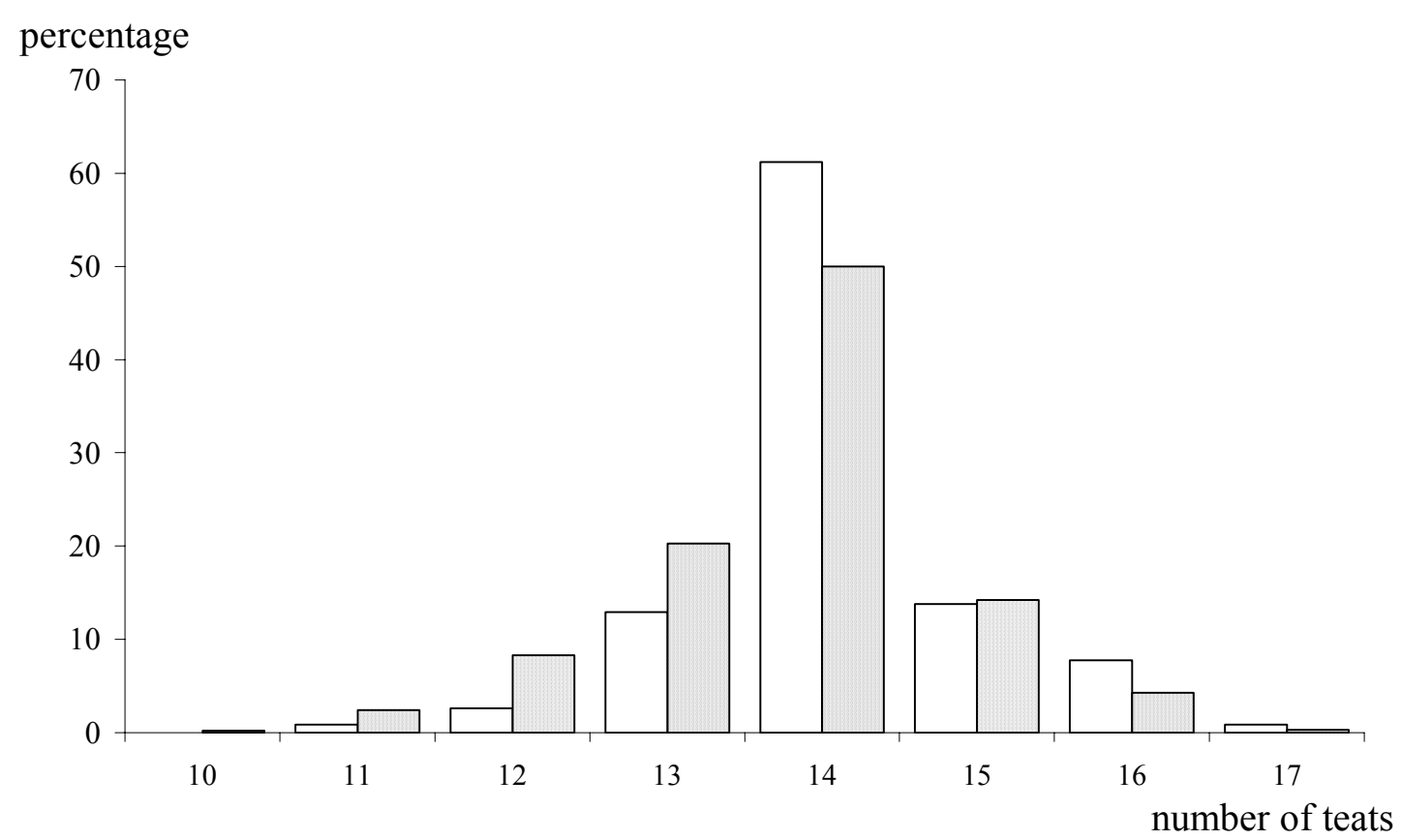

Figure: Distribution of the total teat numbers in the $F_{1}$ (white column) and $F_{2}$ (grey column) (Verteilung der Gesamtanzahl der Zitzen in der $F_{1}$ (weiße Säule) und $F_{2}$ (graue Säule)) 
Two animals were recorded which had only seven or nine teats. They were considered in the group of animals with ten teats. The means and standard deviations for total teat number in the $F_{1}$ were 14.1 and 0.9 , for left side 7.1 teats and 0.5 and for right side 7.0 teats and 0.6. The $\mathrm{F}_{2}$-offspring had an average total teat number of $13.8 \pm 1.0$ and an average of $6.9 \pm 0.6$ on both sides. Most of the $\mathrm{F}_{2}$-animals had 14 teats like the $\mathrm{F}_{1^{-}}$ animals, but mean and standard deviation show a tendency to a reduced teat number with a slightly higher variation. In our experiment each $\mathrm{F}_{2}$-animal had two fullsibs as parents and therefore, if effects of recessive alleles reducing teat number exist, they would become apparent here. An average teat number of 14.1 in the $F_{1}$ and 13.8 in the $\mathrm{F}_{2}$ in crosses involving Piétrain, Landrace and Large White pigs is concordant with the reported average teat number for these breeds in the literature (ALLEN et al., 1959; SKJERVOLD, 1963; HANSET and CAMERLYNCK, 1974; SMITH et al., 1986; ORZECHOWSKA and MUCHA, 1998). The observed phenotypic variation is in good agreement with NACHTSHEIM (1925) who stated that teat number ranges from eight to 18 and that 14 teats are the normal number. In practical experiments NACHTSHEIM (1924), SCHMIDT et al. (1936) and PLUM (1938) could also prove a high phenotypic variance in nipple number, but HANSET and CAMERLYNCK (1974) found an asymmetrical distribution in the Piétrain with a tendency to a lower teat number. However, HANSET and CAMERLYNCK (1974) report only small differences between the means of teat number of the Piétrains and the white breeds and a equal mode of 14 for all three breeds.

An unequal teat number on the left and right side of the body was observed in $29.3 \%$ of the $\mathrm{F}_{1}$-animals and $38.9 \%$ of the $\mathrm{F}_{2}$-animals. These values are in good correspondence with the values of the literature mentioned above. The maximum difference between the left and right side were two teats, contrary to WILLHAM and WHATLEY (1963) who reported a difference of four teats. In agreement with WILLHAM and WHATLEY (1963) and MAYER and PIRCHNER (1995) the heritability for the difference between left and right side teat number was near zero (Table 3).

Table 3

Variance components, $\mathrm{c}^{2}$-effects $\left(\mathrm{c}^{2}\right)$ and heritabilities $\left(\mathrm{h}^{2}\right)$ with corresponding standard errors (SE) of the teat number traits (Varianzkomponenten, $\mathrm{c}^{2}$-Effekte $\left(\mathrm{c}^{2}\right)$ und Heritabilitäten $\left(\mathrm{h}^{2}\right)$ mit den entsprechenden Standardfehlern für die Merkmale der Zitzenzahlen)

\begin{tabular}{lcccccc}
\hline Trait & $\sigma_{\mathrm{A}}^{2(1)}$ & $\sigma_{\mathrm{C}}^{2(2)}$ & $\sigma_{\mathrm{E}}^{2(3)}$ & $\sigma_{\mathrm{P}}^{2(4)}$ & $\mathbf{c}^{2} \pm \mathbf{S E}$ & $\mathbf{h}^{2} \pm \mathbf{S E}$ \\
\hline Total teat number & .227 & .018 & .724 & .969 & $.02 \pm .01$ & $.23 \pm .05$ \\
Left side teat number & .074 & .004 & .284 & .362 & $.01 \pm .01$ & $.20 \pm .05$ \\
Right side teat number & .064 & .003 & .280 & .347 & $.01 \pm .01$ & $.18 \pm .04$ \\
Left minus right side teats & .005 & .001 & .265 & .271 & $.01 \pm .01$ & $.02 \pm .01$ \\
\hline
\end{tabular}

${ }^{(1)} \sigma_{\mathrm{A}}^{2}=$ additive-genetic variance (additv-genetische Varianz), ${ }^{(2)} \sigma_{\mathrm{C}}^{2}=$ variance of the common litter environment (Varianz der gemeinsamen Wurfumwelt), ${ }^{(3)} \sigma_{\mathrm{E}}^{2}=$ residual variance (Restvarianz), ${ }^{(4)} \sigma_{\mathrm{P}}^{2}=$ phenotypic variance (phänotypische Varianz)

The low heritability for the difference between the number of left and right side teats is explained by the very high genetic correlation of 0.96 in our data. This correlation is supported by similar values calculated by WILLHAM and WHATLEY (1963) and SEO et al. (1996). They show that the occurrence of asymmetry is random and due to environmental conditions. Estimates from the literature for the heritability of nipple 
number in Table 1 show a wide range from 0.07 to 0.79 .

Table 4

Number of records (N), LS-Means (LSM), Standard Errors (SE) and Error Probabilities (F-Test) for the effects of teat number on growth and carcass traits (Anzahl Beobachtungen (N), LS-Mittelwerte (LSM), Standardfehler (SE) und Irrtumswahrscheinlichkeiten (F-Test) für die Effekte der Zitzenzahl auf Wachstums- und Schlachtkörpermerkmale)

\begin{tabular}{|c|c|c|c|c|c|c|}
\hline Trait & $\mathbf{N}$ & $\begin{array}{l}\leq 12 \text { teats } \\
\text { LSM (SE) }\end{array}$ & $\begin{array}{c}13 \text { teats } \\
\text { LSM (SE) }\end{array}$ & $\begin{array}{c}14 \text { teats } \\
\text { LSM (SE) }\end{array}$ & $\begin{array}{l}\geq 15 \text { teats } \\
\text { LSM (SE) }\end{array}$ & F-Test \\
\hline \multicolumn{7}{|l|}{ Growth traits } \\
\hline Birth weight (kg) & 2706 & $1.48(.03)$ & $1.54(.03)$ & $1.55(.03)$ & $1.57(.03)$ & .0002 \\
\hline Weaning weight $(\mathrm{kg})$ & 2706 & $6.94(.11)$ & $7.06(.10)$ & $7.08(.09)$ & $7.07(.10)$ & .3818 \\
\hline Starting weight (kg) & 2706 & $25.4(.38)$ & $25.9(.36)$ & $26.0(.33)$ & $26.0(.33)$ & .1319 \\
\hline End weight $(\mathrm{kg})$ & 2696 & $115.5(.24)$ & $115.6(.20)$ & $115.8(.18)$ & $115.8(.21)$ & .3804 \\
\hline Daily gain, pregnancy $(\mathrm{g})$ & 2706 & $12.7(.26)$ & $13.2(.24)$ & $13.2(.23)$ & $13.5(.24)$ & .0002 \\
\hline Daily gain, suckling period $(\mathrm{g})$ & 2706 & $241(4)$ & $246(4)$ & $247(3)$ & $247(4)$ & .2634 \\
\hline Daily gain, rearing period $(\mathrm{g})$ & 2706 & $361(3)$ & $362(3)$ & $360(3)$ & $357(3)$ & .2099 \\
\hline Daily gain, fattening period $(\mathrm{g})$ & 2696 & $664(9)$ & $664(8)$ & $664(8)$ & $662(8)$ & .9905 \\
\hline Live daily gain $(\mathrm{g})$ & 2696 & $535(5)$ & $537(5)$ & $538(4)$ & $537(5)$ & .8670 \\
\hline \multicolumn{7}{|l|}{ Slaughter traits } \\
\hline Live-weight at slaughter (kg) & 2689 & $115.8(.31)$ & $116.0(.28)$ & $116.0(.26)$ & $116.0(.28)$ & .7492 \\
\hline Carcass weight $(\mathrm{kg})$ & 2689 & $89.1(.30)$ & $89.1(.29)$ & $89.2(.27)$ & $89.1(.29)$ & .9082 \\
\hline Dressing out (\%) & 2689 & $76.9(.22)$ & $76.8(.21)$ & $76.8(.20)$ & $76.8(.21)$ & .7224 \\
\hline Abdominal fat $(\mathrm{g})$ & 2672 & $772(30)$ & $758(29)$ & $749(28)$ & $742(29)$ & .1846 \\
\hline \multicolumn{7}{|l|}{ FOM protocol } \\
\hline Loin eye depth (mm) & 2672 & $60.1(.87)$ & $59.2(.85)$ & $59.6(.83)$ & $59.7(.85)$ & .0730 \\
\hline Loin $\mathrm{f}$ & 2672 & $19.4(.62)$ & $19.4(.60)$ & $19.3(.59)$ & $18.8(.60)$ & .0615 \\
\hline Lean & 2687 & $53.7(.58)$ & $53.5(.57)$ & $53.7(.56)$ & $54.0(.57)$ & .1912 \\
\hline Reflectance (1 h p.m.) & 2628 & $22.0(.40)$ & $22.3(.37)$ & $22.4(.36)$ & $22.3(.38)$ & .2981 \\
\hline \multicolumn{7}{|l|}{ Performance test data } \\
\hline $\mathrm{pH}_{1}$ (loin) & 2689 & $6.41(.02)$ & $6.41(.02)$ & $6.42(.02)$ & $6.40(.02)$ & .2166 \\
\hline $\mathrm{pH}_{24}$ (loin) & 2662 & $5.44(.01)$ & $5.44(.01)$ & $5.45(.01)$ & $5.45(.01)$ & .0936 \\
\hline $\mathrm{pH}_{24}$ (ham) & 2662 & $5.57(.02)$ & $5.58(.02)$ & $5.59(.01)$ & $5.59(.02)$ & .3288 \\
\hline Conductivity $(\mathrm{mS}$ ) & 687 & $4.31(.09)$ & $4.39(.08)$ & $4.32(.08)$ & $4.40(.08)$ & .0983 \\
\hline Conductivity (mS/cm, 24 h p.m.) & 2663 & $4.49(.23)$ & $4.60(.23)$ & $4.61(.22)$ & $4.54(.23)$ & .5705 \\
\hline Meat brightness ( 24 h p.m.) & 2664 & $66.9(.74)$ & $66.5(.71)$ & $66.8(.69)$ & $66.8(.71)$ & .5809 \\
\hline \multicolumn{7}{|l|}{ b) Carcass composition } \\
\hline Carcass length $(\mathrm{cm})$ & 2660 & $99.8(.50)$ & $100.2(.49)$ & $100.4(.49)$ & $100.8(.49)$ & $<.0001$ \\
\hline Fat thickn & 2665 & $4.14(.06)$ & $4.06(.05)$ & $4.03(.05)$ & $4.01(.05)$ & .0006 \\
\hline Fat thickness middle of back (cm) & 2665 & $2.43(.06)$ & $2.40(.05)$ & $2.42(.05)$ & $2.36(.05)$ & .0179 \\
\hline Fat thickness end of back $(\mathrm{cm})$ & 2662 & $1.87(.06)$ & $1.85(.06)$ & $1.87(.06)$ & $1.83(.06)$ & .2084 \\
\hline Fat thickness at $m$. latissimus dorsi $(\mathrm{cm})$ & 2665 & $3.25(.09)$ & $3.17(.08)$ & $3.17(.08)$ & $3.09(.08)$ & .0029 \\
\hline Fat thickness over the loin muscle $(\mathrm{cm})$ & 2664 & $1.34(.06)$ & $1.33(.06)$ & $1.31(.06)$ & $1.29(.06)$ & .1819 \\
\hline Loin fat area $\left(\mathrm{cm}^{2}\right)$ & 2664 & $19.3(.60)$ & $19.0(.59)$ & $18.9(.57)$ & $18.8(.59)$ & .3649 \\
\hline Loin eye area $\left(\mathrm{cm}^{2}\right)$ & 2664 & $49.1(.98)$ & $49.2(.95)$ & $49.3(.94)$ & $49.2(.96)$ & .9424 \\
\hline Meat-fat-ratio & 2664 & $.40(.02)$ & $.40(.02)$ & $.39(.02)$ & $.39(.02)$ & .3846 \\
\hline Belly fatness score (1-9) & 2665 & $3.1(.30)$ & $3.3(.29)$ & $3.4(.28)$ & $3.6(.29)$ & .0101 \\
\hline Ham weight $(\mathrm{kg})$ & 2658 & $14.1(.06)$ & $14.0(.06)$ & $14.1(.06)$ & $14.1(.06)$ & .9809 \\
\hline Proportion of ham in carcass (cold) $(\%)$ & 2658 & $32.1(.15)$ & $32.1(.14)$ & $32.1(.13)$ & $32.2(.14)$ & .9910 \\
\hline
\end{tabular}

Most of the estimates are between 0.30 and 0.50 indicating that our heritability estimate of 0.23 is on the lower limit of the interval. Lower heritabilities were computed for left and right side teat number similar as in the study of SEO et al. (1996). A proportion of $2 \%$ of the phenotypic variation of total teat number was due to common litter effects $\left(\mathrm{c}^{2}\right)$ while this proportion was near zero for left and right side teat number. HANSET and CAMERLYNCK (1974) found a proportion of roughly $3.5 \%$ for the common litter environment and ZHANG et al. (2000) proportions 
between $2 \%$ and $5 \%$.

An estimation of a random maternal effect variance was not different from zero. The phenotypic correlation between left and right side teat numbers estimated from raw data was 0.56. Similar values between 0.50 and 0.60 were found by NACHTSHEIM (1925) and SEO et al. (1996), somewhat lower correlations of 0.39 to 0.42 by SKJERVOLD (1963). The phenotypic correlation can be interpreted as a repeatability for teat number counts per side and therefore as an upper limit of the heritability (SKJERVOLD, 1963).

An analysis where the teat number was treated as marker for direct or linked effects revealed a significant influence of teat number on birth weight and daily gain during pregnancy, on carcass length, on the fat thickness at neck, at the middle of the back and at the musculus latissimus dorsi and on the belly fatness score (Table 4). Animals with an increased number of nipples had a higher birth weight and a longer carcass with a reduced fatness. In accordance with these results, LIGONESCHE et al. (1995) reported favourable genetic correlations of total teat number and the number of patent teats with growth and carcass traits.

WADA et al. (2000) detected QTL effects for carcass length and birth weight on chromosome 1. Near the same region CASSADY et al. (2001) found a QTL affecting the number of nipples. This is in good agreement with our results, if there exists linkage between QTL for these traits or a single QTL with pleiotropic effects on all three traits. Further QTL for teat number are reported on chromosomes 2, 3, 6, 7, 8, 10, 11 and 12 (WADA et al., 2000; BIDANEL et al., 2000; ROHRER, 2000; CASSADY et al., 2001; HIROOKA et al., 2001). HIROOKA et al. (2001) suggested that imprinting plays an important role in the expression of teat number. Significant effects of teat number as a phenotypic marker could therefore be due to the confined pleiotropic effects of one or several of these and other yet undetected QTL or due to linkage.

\section{Hairiness}

The density of hairiness in the $\mathrm{F}_{2}$-offspring varied from near hairless to very dense haired. A heritability estimate of $0.27 \pm 0.07$ (Table 5) and proportions of $0.06 \pm 0.02$ and of $0.02 \pm 0.01$ due to common litter environment effects and to maternal effects were estimated.

Table 5

Variance components of the traits hairiness and set of ears and the corresponding $\mathrm{c}^{2}$-effects $\left(\mathrm{c}^{2}\right)$, maternal effects $\left(\mathrm{m}^{2}\right)$, heritabilities $\left(\mathrm{h}^{2}\right)$ and standard errors (SE) (Geschätzte Varianzkomponenten für die Merkmale Behaarung und Ohrform sowie die entsprechenden Wurfumwelteffekte $\left(\mathrm{c}^{2}\right)$, maternalen Effekte $\left(\mathrm{m}^{2}\right)$, Heritabilitäten $\left(\mathrm{h}^{2}\right)$, und Standardfehler (SE))

\begin{tabular}{lcccccccc}
\hline Trait & $\sigma_{\mathrm{A}}^{2(1)}$ & $\sigma_{\mathrm{C}}^{2(2)}$ & $\sigma_{\mathrm{M}}^{2}{ }^{(3)}$ & $\sigma_{\mathrm{E}}^{2(4)}$ & $\sigma_{\mathrm{P}}^{2(5)}$ & $\mathbf{c}^{2} \pm \mathbf{S E}$ & $\mathbf{m}^{2} \pm \mathbf{S E}$ & $\mathbf{h}^{2} \pm \mathbf{S E}$ \\
\hline Hairiness & .062 & .015 & .005 & .144 & .226 & $.06 \pm .02$ & $.02 \pm .01$ & $.27 \pm .07$ \\
Set of ears & .099 & .009 & .007 & .148 & .263 & $.03 \pm .01$ & $.03 \pm .02$ & $.37 \pm .08$ \\
\hline
\end{tabular}

${ }^{(1)} \sigma_{\mathrm{A}}^{2}=$ additive-genetic variance (additiv-genetische Varianz), ${ }^{(2)} \sigma_{\mathrm{C}}^{2}=$ variance of the common litter environment (Varianz der gemeinsamen Wurfumwelt), ${ }^{(3)} \sigma_{\mathrm{M}}^{2}=$ variance due to maternal effects (durch maternale Effekte verursachte Varianz), ${ }^{(4)} \sigma_{\mathrm{E}}^{2}=$ residual variance (Restvarianz), ${ }^{(5)} \sigma_{\mathrm{P}}^{2}=$ phenotypic variance (phänotypische Varianz)

A reduced number of hair follicles was probably inherited by the Piétrain boars 
because of the observation of nearly hairless animals in purebred Piétrains occasionally made by the author.

From Table 6 can be drawn that the gene or genes for a reduced density of hairiness are present in the progeny of the Piétrain boars "Florian", "Vehemenz" and "Vento". In contrast to these pigs the offspring of the boars "Felix" and "Mike" were very densely haired.

Table 6

Results of the judgement for hairiness and set of ears; the percental proportion and number of animals (in brackets) listed by Piétrain boar and category (Beurteilungsergebnisse für Behaarung und Ohrform; prozentualer Anteil und Anzahl der Tiere aufgelistet nach Piétraineber und Kategorie)

\begin{tabular}{|c|c|c|c|c|c|c|c|c|c|c|c|c|c|}
\hline \multirow{3}{*}{$\begin{array}{c}\text { Piétrain } \\
\text { boar }\end{array}$} & & \multicolumn{6}{|c|}{ Hairiness } & \multicolumn{6}{|c|}{ Set of ears } \\
\hline & & \multicolumn{2}{|c|}{1} & \multicolumn{2}{|c|}{2} & \multicolumn{2}{|c|}{3} & \multicolumn{2}{|c|}{1} & \multicolumn{2}{|c|}{2} & \multicolumn{2}{|c|}{3} \\
\hline & & $\%$ & $(\mathbf{N})$ & $\%$ & $(\mathbf{N})$ & $\%$ & $(\mathbf{N})$ & $\%$ & $(\mathbf{N})$ & $\%$ & $(\mathbf{N})$ & $\%$ & (N) \\
\hline \multirow[t]{2}{*}{ Felix } & $\mathrm{F}_{1}$ & 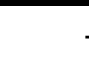 & 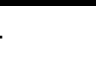 & 95.0 & (19) & 5.0 & (1) & 5.0 & (1) & 80.0 & (16) & 15.0 & (3) \\
\hline & $\mathrm{F}_{2}$ & 0.2 & (1) & 61.6 & (307) & 38.2 & (190) & 9.6 & (48) & 75.9 & (378) & 14.5 & (72) \\
\hline \multirow[t]{2}{*}{ Florian } & $\mathrm{F}_{1}$ & & 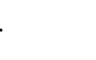 & 100.0 & (27) & - & - & 11.1 & (3) & 85.2 & (23) & 3.7 & (1) \\
\hline & $\mathrm{F}_{2}$ & 12.7 & (96) & 79.9 & (603) & 7.4 & (56) & 14.0 & (106) & 75.9 & (573) & 10.1 & (76) \\
\hline \multirow[t]{2}{*}{ Mike } & $\mathrm{F}_{1}$ & & . & 85.0 & (17) & 18.0 & (3) & - & - & 75.0 & (15) & 25.0 & (5) \\
\hline & $\mathrm{F}_{2}$ & & . & 44.5 & (190) & 55.5 & (237) & 2.3 & (10) & 59.0 & (252) & 38.7 & (165) \\
\hline \multirow[t]{2}{*}{ Vento } & $\mathrm{F}_{1}$ & & . & 100.0 & (26) & & - & . & - & 96.2 & (25) & 3.8 & (1) \\
\hline & $\mathrm{F}_{2}$ & 7.8 & (48) & 77.9 & (480) & 14.3 & (88) & 12.5 & (77) & 79.2 & (488) & 8.3 & (51) \\
\hline \multirow[t]{2}{*}{ Vehemenz } & $\mathrm{F}_{1}$ & & - & 100.0 & $(20)$ & & - & - & - & 30.0 & (6) & 70.0 & (14) \\
\hline & $\mathrm{F}_{2}$ & 12.0 & (57) & 76.2 & $(361)$ & 11.8 & (56) & 5.5 & (26) & 63.1 & (299) & 31.4 & (149) \\
\hline \multirow{2}{*}{$\begin{array}{c}\text { Pigs per } \\
\text { generation }\end{array}$} & $\mathrm{F}_{1}$ & . & 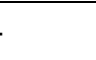 & 96.5 & (109) & 3.5 & (4) & 3.5 & (4) & 75.2 & (85) & 21.2 & (24) \\
\hline & $\mathrm{F}_{2}$ & 7.3 & (202) & 70.1 & (1941) & 22.6 & (627) & 9.6 & (267) & 71.9 & (1990) & 18.5 & (513) \\
\hline All pigs & & 7.0 & (202) & 71.1 & (2050) & 21.9 & (631) & 9.4 & (271) & 72.0 & (2075) & 18.6 & $(537)$ \\
\hline
\end{tabular}

In the $F_{1}$ no little haired animals were observed. This is possibly due to recessive alleles responsible for the density of hairiness. ROBERTS and CARROLL (1931) described a simple intermediate mode of inheritance for the hairiness in Mexican Poland Chinas, where the allele for little hairiness is recessive. In our investigation the density of hairiness also seems to be inherited recessively. Whether the Piétrain boars have the same kind of hairlessness can not be concluded, but it is possible, because the Poland Chinas have the Berkshires as ancestors like the Piétrain.

Like teat number the trait hairiness was also used as a marker for direct or linked effects (Table 7). Significant effects for hairiness were obtained for birth weight, dressing out percentage, abdominal fat, loin eye depth, $\mathrm{pH}_{24}$ of the ham, carcass length and loin eye area. The animals scored as "little hairy" are on the one hand in some traits more similar to purebred Piétrains because they had a shorter carcass, a higher dressing out percentage, a thicker loin eye depth and a larger loin eye area. On the other hand they had a higher weight of the abdominal fat and a higher $\mathrm{pH}_{24}$ in the ham. In our experiment a good meat quality can be expected because all Piétrain boars were genetically stress resistant. The obtained results suggest that QTL alleles for less hairiness are linked with Piétrain specific alleles for higher muscularity and cryptic alleles for abdominal fat weight. 
Table 7

Number of records (N), LS-Means (LSM), Standard Errors (SE) and Error Probabilities (F-Test) for the effects of hairiness on growth and carcass traits (Anzahl Beobachtungen (N), LS-Mittelwerte (LSM), Standardfehler (SE) und Irrtumswahrscheinlichkeiten (F-Test) für die Effekte der Behaarung auf Wachstums- und Schlachtkörpermerkmale)

\begin{tabular}{|c|c|c|c|c|c|}
\hline Trait & $\mathbf{N}$ & $\begin{array}{c}1 \\
\text { little hairy }\end{array}$ & $\begin{array}{c}2 \\
\text { normal hairy }\end{array}$ & $\begin{array}{c}3 \\
\text { very hairy }\end{array}$ & F-Test \\
\hline \multicolumn{6}{|l|}{ Growth traits } \\
\hline Birth weight (kg) & 2770 & $1.56(.03)$ & $1.55(.03)$ & $1.52(.03)$ & .0489 \\
\hline Weaning weight (kg) & 2770 & $6.97(.12)$ & $7.11(.09)$ & $7.04(.10)$ & .2376 \\
\hline Starting weight (kg) & 2770 & $25.3(.43)$ & $25.8(.33)$ & $26.0(.36)$ & .1747 \\
\hline End weight $(\mathrm{kg})$ & 2718 & $115.4(.29)$ & $115.6(.17)$ & $115.7(.21)$ & .4538 \\
\hline Daily gain, pregnancy $(\mathrm{g})$ & 2770 & $13.3(.28)$ & $13.3(.22)$ & $13.0(.24)$ & .0747 \\
\hline Daily gain, suckling period (g) & 2770 & $241(5)$ & $247(3)$ & $245(4)$ & .2657 \\
\hline Daily gain, rearing period $(\mathrm{g})$ & 2770 & $363(4)$ & $360(3)$ & $358(3)$ & .1778 \\
\hline Daily gain, fattening period $(\mathrm{g})$ & 2718 & $664(9)$ & $664(8)$ & $659(8)$ & .3984 \\
\hline Live daily gain $(\mathrm{g})$ & 2718 & $535(5)$ & $538(4)$ & $535(5)$ & .3139 \\
\hline \multicolumn{6}{|l|}{ Slaughter traits } \\
\hline Live-weight at slaughter $(\mathrm{kg})$ & 2682 & $115.7(.33)$ & $116.0(.26)$ & $116.0(.28)$ & .3646 \\
\hline Carcass weight $(\mathrm{kg})$ & 2682 & $89.1(.33)$ & $89.1(.27)$ & $88.9(.29)$ & .2939 \\
\hline Dressing out $(\%)$ & 2682 & $77.0(.23)$ & $76.9(.20)$ & $76.7(.21)$ & .0285 \\
\hline Abdominal fat $(\mathrm{g})$ & 2650 & $776(31)$ & $746(28)$ & $764(29)$ & .0322 \\
\hline \multicolumn{6}{|l|}{ FOM protocol } \\
\hline Loin eye depth (mm) & 2650 & $60.4(.90)$ & $59.8(.83)$ & $59.0(.85)$ & .0058 \\
\hline Loin fat depth (mm) & 2650 & $19.3(.63)$ & $19.1(.58)$ & $19.4(.60)$ & .1630 \\
\hline Lean meat content $(\%)$ & 2680 & $53.9(.60)$ & $53.8(.55)$ & $53.4(.57)$ & .0709 \\
\hline Reflectance (1 h p.m.) & 2608 & $22.5(.42)$ & $22.3(.35)$ & $22.3(.37)$ & .7979 \\
\hline \multicolumn{6}{|l|}{ Performance test data } \\
\hline \multicolumn{6}{|l|}{ a) Meat quality } \\
\hline $\mathrm{pH}_{1}$ (loin) & 2681 & $6.42(.02)$ & $6.42(.02)$ & $6.41(.02)$ & .7661 \\
\hline $\mathrm{pH}_{24}$ (loin) & 2649 & $5.46(.01)$ & $5.45(.01)$ & $5.45(.01)$ & .2004 \\
\hline $\mathrm{pH}_{24}$ (ham) & 2649 & $5.61(.02)$ & $5.59(.01)$ & $5.57(.02)$ & .0054 \\
\hline Conductivity (mS/cm, 1 h p.m.) & 2679 & $4.31(.10)$ & $4.34(.08)$ & $4.35(.09)$ & .8069 \\
\hline Conductivity (mS/cm, 24 h p.m.) & 2650 & $4.46(.24)$ & $4.55(.22)$ & $4.61(.23)$ & .5874 \\
\hline Meat brightness ( 24 h p.m.) & 2651 & $67.4(.77)$ & $66.8(.68)$ & $66.7(.71)$ & .2523 \\
\hline \multicolumn{6}{|l|}{ b) Carcass composition } \\
\hline Carcass length $(\mathrm{cm})$ & 2646 & $99.9(.50)$ & $100.3(.47)$ & $100.6(.48)$ & .0031 \\
\hline Fat thickness neck $(\mathrm{cm})$ & 2652 & $4.03(.06)$ & $4.03(.05)$ & $4.07(.05)$ & .3782 \\
\hline Fat thickness middle of back (cm) & 2652 & $2.44(.06)$ & $2.40(.05)$ & $2.40(.05)$ & .2997 \\
\hline Fat thickness end of back $(\mathrm{cm})$ & 2649 & $1.92(.07)$ & $1.85(.06)$ & $1.86(.06)$ & .1160 \\
\hline Fat thickness at $m$. latissimus dorsi $(\mathrm{cm})$ & 2652 & $3.24(.09)$ & $3.15(.08)$ & $3.17(.09)$ & .0873 \\
\hline Fat thickness over the loin muscle $(\mathrm{cm})$ & 2651 & $1.32(.06)$ & $1.31(.06)$ & $1.33(.06)$ & .4546 \\
\hline Loin fat area $\left(\mathrm{cm}^{2}\right)$ & 2651 & $19.3(.62)$ & $18.9(.56)$ & $19.1(.58)$ & .1967 \\
\hline Loin eye area $\left(\mathrm{cm}^{2}\right)$ & 2651 & $50.0(1.01)$ & $49.4(.94)$ & $48.6(.96)$ & .0028 \\
\hline Meat-fat-ratio & 2651 & $.40(.02)$ & $.39(.02)$ & $.40(.02)$ & .1112 \\
\hline Belly fatness score (1-9) & 2652 & $3.3(.32)$ & $3.4(.28)$ & $3.3(.29)$ & .5053 \\
\hline Ham weight $(\mathrm{kg})$ & 2646 & $14.0(.07)$ & $14.1(.06)$ & $14.1(.06)$ & .2517 \\
\hline Proportion of ham in carcass (cold) $(\%)$ & 2646 & $32.0(.16)$ & $32.1(.13)$ & $32.2(.14)$ & .2002 \\
\hline
\end{tabular}

\section{Set of ears}

Several distinct forms of ears from prick, as shown by Large White pigs, to lop, as shown by Landrace pigs, were observed in the $F_{1}$ - and $F_{2}$-offspring. Between these two extremes many intermediate types were observed, e.g. forward directed ears as in the Piétrain breed or lateral directed ears. The aim of our judgement was to separate the prick-eared pigs (categories 1 and 2) from the lop-eared pigs. Assuming that lop is simple dominant most of the $F_{1}$-animals had to be lop-eared, because 13 of the P-dams were Landrace or Landrace $\times$ Large White pigs. But in the $F_{1}$ only four pigs had lop 
ears and in the $\mathrm{F}_{2}$ the proportion of lop-eared pigs was $18.6 \%$ (Table 6).

It can be concluded from these scoring results, in accordance to CARR-SAUNDERS (1922) and in contrast to PORTER and TEBBIT (1993), that prick is dominant and lop is recessive.

Table 8

Number of records (N), LS-Means (LSM), Standard Errors (SE) and Error Probabilities (F-Test) for the effects of the set of ears on growth and carcass traits (Anzahl Beobachtungen (N), LS-Mittelwerte (LSM), Standardfehler (SE) und Irrtumswahrscheinlichkeiten (F-Test) für die Effekte der Ohrform auf Wachstums- und Schlachtkörpermerkmale)

\begin{tabular}{|c|c|c|c|c|c|}
\hline Trait & $\mathbf{N}$ & $\begin{array}{c}1 \\
\text { prick-eared }\end{array}$ & $\begin{array}{c}2 \\
\text { intermediate }\end{array}$ & $\begin{array}{c}3 \\
\text { lop-eared }\end{array}$ & F-Test \\
\hline \multicolumn{6}{|l|}{ Growth traits } \\
\hline Birth weight (kg) & 2770 & $1.51(.03)$ & $1.53(.03)$ & $1.62(.03)$ & $<.0001$ \\
\hline Weaning weight (kg) & 2770 & $7.05(.12)$ & $7.03(.09)$ & $7.28(.10)$ & .0007 \\
\hline Starting weight $(\mathrm{kg})$ & 2770 & $25.7(.41)$ & $25.7(.35)$ & $26.3(.38)$ & .0154 \\
\hline End weight $(\mathrm{kg})$ & 2718 & $115.0(.26)$ & $115.7(.18)$ & $115.8(.22)$ & .0124 \\
\hline Daily gain, pregnancy (g) & 2770 & $12.9(.25)$ & $13.1(.22)$ & $13.8(.24)$ & $<.0001$ \\
\hline Daily gain, suckling period (g) & 2770 & $245(4)$ & $245(3)$ & $251(4)$ & .0537 \\
\hline Daily gain, rearing period $(\mathrm{g})$ & 2770 & $359(4)$ & $359(3)$ & $362(3)$ & .2894 \\
\hline Daily gain, fattening period $(\mathrm{g})$ & 2718 & $668(9)$ & $660(8)$ & $671(8)$ & .0129 \\
\hline Live daily gain $(\mathrm{g})$ & 2718 & $538(5)$ & $534(4)$ & $545(5)$ & .0003 \\
\hline \multicolumn{6}{|l|}{ Slaughter traits } \\
\hline Live-weight at slaughter (kg) & 2682 & $115.5(.32)$ & $116.0(.26)$ & $116.1(.28)$ & .0451 \\
\hline Carcass weight $(\mathrm{kg})$ & 2682 & $88.9(.31)$ & $89.1(.27)$ & $89.1(.29)$ & .6030 \\
\hline Dressing out $(\%)$ & 2682 & $77.0(.22)$ & $76.8(.20)$ & $76.8(.21)$ & .2076 \\
\hline Abdominal fat (g) & 2650 & $759(30)$ & $750(28)$ & $753(29)$ & .7828 \\
\hline \multicolumn{6}{|l|}{ FOM protocol } \\
\hline Loin eye depth (mm) & 2650 & $59.9(.87)$ & $59.6(.82)$ & $59.7(.84)$ & .6541 \\
\hline Loin fat depth (mm) & 2650 & $19.2(.61)$ & $19.2(.58)$ & $19.3(.59)$ & .8147 \\
\hline Lean meat content $(\%)$ & 2680 & $53.8(.58)$ & $53.8(.55)$ & $53.7(.56)$ & .8781 \\
\hline Reflectance (1 h p.m.) & 2608 & $22.8(.41)$ & $22.3(.35)$ & $22.3(.37)$ & .0922 \\
\hline \multicolumn{6}{|l|}{ Performance test data } \\
\hline \multicolumn{6}{|l|}{ a) Meat quality } \\
\hline $\mathrm{pH}_{1}$ (loin) & 2681 & $6.39(.02)$ & $6.42(.02)$ & $6.42(.02)$ & .1130 \\
\hline $\mathrm{pH}_{24}$ (loin) & 2649 & $5.45(.01)$ & $5.45(.01)$ & $5.45(.01)$ & .7733 \\
\hline $\mathrm{pH}_{24}$ (ham) & 2649 & $5.59(.02)$ & $5.58(.02)$ & $5.58(.02)$ & .6553 \\
\hline Conductivity (mS/cm, 1 h p.m.) & 2679 & $4.30(.09)$ & $4.32(.08)$ & $4.38(.09)$ & .3011 \\
\hline Conductivity (mS/cm, 24 h p.m.) & 2650 & $4.72(.24)$ & $4.55(.22)$ & $4.52(.23)$ & .2371 \\
\hline Meat brightness (24 h p.m.) & 2651 & $67.0(.75)$ & $66.9(.69)$ & $66.6(.71)$ & .5564 \\
\hline \multicolumn{6}{|l|}{ b) Carcass composition } \\
\hline Carcass length $(\mathrm{cm})$ & 2646 & $100.1(.49)$ & $100.4(.47)$ & $100.3(.48)$ & .0948 \\
\hline Fat thickness neck $(\mathrm{cm})$ & 2652 & $4.07(.06)$ & $4.04(.05)$ & $4.04(.05)$ & .4823 \\
\hline Fat thickness middle of back $(\mathrm{cm})$ & 2652 & $2.43(.06)$ & $2.39(.05)$ & $2.41(.05)$ & .2706 \\
\hline Fat thickness end of back $(\mathrm{cm})$ & 2649 & $1.84(.06)$ & $1.85(.06)$ & $1.88(.06)$ & .4610 \\
\hline Fat thickness at $m$. latissimus dorsi $(\mathrm{cm})$ & 2652 & $3.18(.09)$ & $3.16(.08)$ & $3.15(.09)$ & .7899 \\
\hline Fat thickness over the loin muscle $(\mathrm{cm})$ & 2651 & $1.32(.06)$ & $1.31(.05)$ & $1.32(.06)$ & .9980 \\
\hline Loin fat area $\left(\mathrm{cm}^{2}\right)$ & 2651 & $19.0(.60)$ & $18.9(.56)$ & $19.1(.58)$ & .6682 \\
\hline Loin eye area $\left(\mathrm{cm}^{2}\right)$ & 2651 & $49.8(.98)$ & $49.2(.93)$ & $49.2(.95)$ & .2243 \\
\hline Meat-fat-ratio & 2651 & $.39(.02)$ & $.39(.02)$ & $.40(.02)$ & 6900 \\
\hline Belly fatness score (1-9) & 2652 & $3.2(.31)$ & $3.3(.28)$ & $3.5(.30)$ & .2918 \\
\hline Ham weight $(\mathrm{kg})$ & 2646 & $14.1(.07)$ & $14.0(.06)$ & $14.1(.06)$ & .9670 \\
\hline Proportion of ham in carcass (cold) $(\%)$ & 2646 & $32.1(.15)$ & $32.1(.13)$ & $32.2(.14)$ & .9765 \\
\hline
\end{tabular}

From the analyses where the set of ears was considered as a marker (Table 8) a significant effect was obtained only for growth traits. Lop-eared pigs had a higher weight at birth, at weaning, at the beginning of the fattening period and its end. Also higher corresponding daily gains were observed. From performance test station results 
it is known that the Landrace pigs have a superior growth performance compared to Piétrains (KETELS, 1998). A locus for lop ears may therefore be associated with Landrace specific QTL alleles for growth.

In mice many mutants with ear defects are known. The defects occur as "droopy" ears reduced ears, hairy ears, low set ears and small ears (BUNDY, 1950; CURRY, 1959; LANE and LIU, 1984; THEILER and SWEET, 1986; RASBERRY and CATTANACH, 1988; LYON et al., 1996). "Droopy" ear is mapped to chromosome 3 , the dominant reduced ear to chromosome 4 and the short ear to chromosome 9 of the mouse genome (URL: http://www.ihr.mrc.ac.uk/hereditary/MutantsTable.shtml). These results maybe useful for the detection of QTL responsible for set of ears in pigs. The knowledge of QTL for the set of ears can help to breed pigs with desirable ear forms, because pigs with large lop ears are often frightened when they have to move.

\section{4.}

\section{Conclusions}

From our results and the current knowledge on the inheritance of these traits it can be concluded that teat number is less suitable as a phenotypic marker, because this trait seems to be polygenic inherited and there is virtually no difference in teat number between the founder lines of our experiment. In contrast to teat number both the significant effects on performance traits and the presumably monogenic inheritance suggest that "lop-ear" could serve as a marker for Landrace alleles and "little hairy" for Piétrain alleles in similar crossbreeding experiments.

\section{References}

ALLEN, A.D.; TRIBBLE, L.F.; LASLEY, J.F.:

Inheritance of nipple number in swine and the relationship to performance. Mo. Agric. Exp. Sta., Res. Bull. No. 694 (1959)

BIDANEL, J.P.; MILAN, D.; IANNUCCELLI, N.; AMIGUES, Y.; BOSCHER, M.Y.; BOURGEOIS, F.; CARITEZ, J.C.; GRUAND, J.; LE ROY, P.; LAGANT, H.; BONNEAU, M.; LEFAUCHEUR, L.; MOUROT, J.; PRUNIER, A.; DÉSAUTÉS, C.; MORMĖDE, P.; RENARD, C.; VAIMAN, M.; ROBIC, A.; GELLIN, J.; OLLIVIER, L.; CHEVALET, C.:

Détection de locus à effets quantitatifs dans le croisement entre les races porcines Large White et BORCHERS, N.: Meishan: résultats et perspectives. Journ. Rech. Porc. Fr. 32 (2000), 369-383

Establishing a Piétrain $\mathrm{F}_{2}$-resource-population and analysing several phenotypes as markers. $\mathrm{PhD}$ BUNDY, R.E.: Thesis, University Kiel, Germany (2002)

A search for some effects of the "short-ear" gene on behavior in mice. Am. Nat. 84 (1950), 393-399

CARR-SAUNDERS, A.M.:

Note on inheritance in swine. Science 55 (1922), 19

CASSADY, J.P.; JOHNSON, R.K.; POMP, D.; ROHRER, G.A.; VAN VLECK, L.D.; SPIEGEL, E.K.; GILSON, K.M.: Identification of quantitative trait loci affecting reproduction in pigs. J. Anim. Sci. 79 (2001) 3, 623-633

CLAYTON, G.A.; POWELL, J.C.; HILEY, P.G.: Inheritance of teat number and teat inversion in pigs. Anim. Prod. 33 (1981), 299-304

CURRY, G.A.:

Genetical and developmental studies on droopy-eared mice. J. Embryol. Exp. Morphol. 7 (1959), 39-65

ENFIELD, F.D.; REMPEL, W.E.: Inheritance of teat number and relationship of teat number to various maternal traits in swine. J. Anim. Sci. 20 (1961), 876-879

GAUR, G.K.; CHHABRA, A.K.:

Inheritance of teat number in swine. Ind. J. Anim. Sci. 31 (1995), 51-53 
HALEY, C.S.; LEE, G.J.; RITCHIE, M.:

Comparative reproductive performance in Meishan and Large White pigs and their crosses. Anim. Sci. 60 (1995), 259-267

HANSET, R.; CAMERLYNCK, R.:

L’Héritabilité du nombre de mamelles chez le porc de Piétrain et le porc Landrace Belge. Ann. Génét. Sél. Anim. 6 (1974) 1, 91-102

HIROOKA, H.; DE KONING, D.J.; HARLIZIUS, B.; VAN ARENDONK, J.A.M.; RATTINK, A.P. ; GROENEN, M.A.M.; BRASCAMP, E.W. ; BOVENHUIS, H.: A whole-genome scan for quantitative trait loci affecting teat number in pigs. J. Anim. Sci. 79 (2001), $2320-2326$

KETELS, O.:

Zerlegekalkulation bei Jungbullen und ökonomische Bewertung der Schlachtnebenprodukte bei Jungbullen und Mastschweinen. PhD Thesis, University Kiel, Germany (1998)

KUCIEL, J.; CHVATALOVA, H.:

Heritability of teat number in Czech improved white pigs. Acta Univ. Agric., Fac. Agron. 40 (3-4) (1992), 301-306

LANE, P.W.; LIU, H.M.:

Association of megacolon with a new dominant spotting gene (Dom) in the mouse. J. Hered. 75 (1984), 435-439

LEE, C.; WANG, C.D.:

Bayesian inference on variance components using Gibbs sampling with various priors. Asian Australasian J. Anim. Sci. 14 (2001) 8, 1051-1056

LIGONESCHE, B.; BAZIN, C.; BIDANEL, J.P.:

Variabilité génétique du nombre de tétines chez le porc. Relations avec les caractères de production et de reproduction. Journ. Rech. Porc. Fr. 27 (1995), 121-125

LIU, W.H.; ZHANG, S.Z.; ZHOU, Z.X.; XUE, S.J.; ZHANG, X.Q.; JIAO, D.S.:

Genetic parameters of teat number and the inheritance of inverted teats in pigs. Acta Vet. Zoot. Sin. 26 (1995) $5,408-413$

LÖFFLER, K.: Anatomie und Physiologie der Haustiere. 8. Auflage, Eugen Ulmer Verlag, Stuttgart, Germany (1991)

LYON, M.F.; RASTAN, S.; BROWN, S.D.M.:

Genetic variants and strains of the laboratory mouse. International Committee on Standardized Genetic Nomenclature for Mice, Third Edition, Oxford University Press (1996)

MAYER, J.; PIRCHNER, F.: Gesäugeasymmetrie und Stülpzitzenbefall bei Jungsauen. Arch. Tierz., Dummerstorf 38 (1995) 1, 87-91

MCKAY, R.M.; RAHNEFELD, G.W.:

Heritability of teat number in swine. Can. J. Anim. Sci. 70 (1990) 2, 425-430

MEYER, H.; DROMMER, W.:

Erbliche Hypotrichie beim Schwein. Dt. tierärztl. Wochenschr. 75 (1968), 13-17

NACHTSHEIM, H.:

Studies on the inheritance in swine. The inheritance of teat number. Z. indukt. Abstamm. Vererbungsl. 33 (1924), 307-311

NACHTSHEIM, H.:

Untersuchungen über Variation und Vererbung des Gesäuges beim Schwein. J. Anim. Breed. Genet. 2 (1925), 113-161

NORDBY, J.E.:

Inheritance of whorls in the hair of swine. J. Hered. 23 (1932), 397-404

ORZECHOWSKA, B.; MUCHA, A.:

An evaluation of reproductive efficiency of sows. Stan Hodowli i Wyniki Oceny Świń w Roku 16

PLUM, M.: (1998), 27-49

Inheritance of mammae in swine a character involving partly symmetrical organs. Hereditas 24 (1938), $216-230$

PORTER, V.; TEBBIT, J.:

A handbook to breeds of the world. Helm Information, Mountfield East Sussex, United Kingdom (1993)

PUMFREY, R.A.; JOHNSON, R.K.; CUNNINGHAM, P.J.; ZIMMERMAN, D.R.:

Inheritance of teat number and its relationship to maternal traits in swine. J. Anim. Sci. 50 (1980) 6, 1057-1060

RASBERRY, C.; CATTANACH, B. M.: 
Small ear, a new dominant mutation. Mouse News Lett. 80 (1988), 158-159

REINSCH, N.:

Two FORTRAN programs for the Gibbs sampler in univariate linear mixed models. Arch. Tierz., Dummerstorf 39 (1996), 203-209

RHOAD, A. O.:

Woolly hair in swine. J. Hered. 25 (1934), 371-375

ROBERTS, E.; CARROLL, W.E.:

The inheritance of "hairlessness" in swine. Hypotrichosis II. J. Hered. 22 (1931), 125-132

ROHRER, G.A.:

Identification of quantitative trait loci affecting birth characters and accumulation of backfat and weight in a Meishan-White composite resource population. J. Anim. Sci. 78 (2000), 2547-2553

SAS:

SAS User's Guide, Version 6. SAS Institute Inc., Cary, NC, USA (1992)

SCHMIDT, J.; LAUPRECHT, E.; STAUBESAND, H.:

Untersuchungen über die Vererbung der Trächtigkeitsdauer. des Geburtsgewichtes und der Zitzenzahl beim Schwein. J. Anim. Breed. Genet. 36 (1936), 55-100

SEO, K.S.; KIM, S.H.; PARK, Y.I.:

Estimation of genetic parameters for teat number in pigs. Korean J. Anim. Sci. 38 (2) (1996), 133-138

SKJERVOLD, H.:

Inheritance of teat number in swine and the relationship to performance. Acta Agric. Scand. 13 (1963), 323-333

SMITH, P.R.; MCPHEE, C.P.; NATOLI, W.J.:

Heritability of teat number and its relationship to production characters in male pigs. Aust. J. Exp. Agric. 26 (5) (1986), 539-541

THEILER, K.; SWEET, H.O.:

Low set ears (Lse), a new mutation of the house mouse. Anat. Embryol. 175 (1986), 241-246

WADA, Y.; AKITA, T.; AWATA, T.; FURUKAWA, T.; SUGAI, N.; INAGE, Y.; ISHII, K.; ITO, Y.; KOBAYASHI, E.; KUSUMOTO, H.; MATSUMOTO, T.; MIKAWA, S.; MIYAKE, M.; MURASE, A.; SHIMANUKI, S.; SUGIYAMA, T.; UCHIDA, Y.; YANAI, S.; YASUE, H.:

Quantitative trait loci (QTL) analysis in a Meishan $\times$ Göttingen cross population. Anim. Genet. 31 (2000), 376-384

WANG, C.D.; CHEN, Q.M.; ZHOU, W.L.; WANG, Z.Q.; HAN, S.Y.; LI, Z.K.:

Bayesian inference of teat number in Landrace using Gibbs sampling. J. China Agric. Univ. 5 (2000) 3, 92-95

WATSON, S.A.J.; MOORE, G.P.M.:

Postnatal development of the hair cycle in the domestic pig. J. Anat. 170 (1990), 1-9

WENTWORTH, E.N.:

Inheritance of mammae in Duroc-Jersey swine. Am. Nat. 47 (1913), 257-279

WILLHAM, R.L.; WHATLEY, J.A.:

Genetic variation in nipple number in swine. J. Anim. Breed. Genet. 78 (1963), 350-363

ZHANG, S.; BIDANEL, J.P.; BURLOT, T.; LEGAULT, C.; NAVEAU, J.:

Genetic parameters and genetic trends in the Chinese $\times$ European Tiameslan composite pig line. I. Genetic parameters. Genet., Sel., Evol. 32 (2000), 41-47

Received: 2002-06-04

Accepted: 2002-08-01

Authors address

NORBERT BORCHERS, PD Dr. NORBERT REINSCH,

Prof. Dr. Dr. h.c. mult. ERNST KALM

Institut für Tierzucht und Tierhaltung der Christian-Albrechts-Universität zu Kiel

Olshausenstr. 40

D-24098 Kiel

Germany

E-Mail: nborchers@tierzucht.uni-kiel.de 